$14^{\text {th }}$ Conf. Agric. Develop. Res., Fac. of Agric., Ain Shams Univ.,

March, 2019, Cairo, Egypt

Special Issue, 27(1), 761 - 773, 2019

Website: http://strategy-plan.asu.edu.eg/AUJASCI/

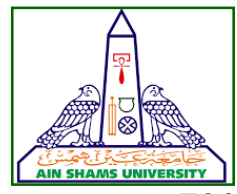

\title{
EFFECT OF FOLIAR APPLICATION OF POTASSIUM SILICATE AND SOME POSTHARVEST TREATMENTS ON GROWTH, PRODUCTIVITY AND STORABILITY OF GARLIC
}

\author{
Amany A. Abdel-Latif ${ }^{*}$, Nadia M. Ibrahim and Shadia A. Ismail \\ Potatoes and Vegetables Reproduction Dept. - Horticulture Research Institute, Giza, Egypt \\ ${ }^{*}$ Corresponding author:nadia_mohamed33@yahoo.com
}

Received 20 February, 2019, $\quad$ Accepted 26 May, 2019

\begin{abstract}
Two experiments were carried out in the experimental farm of Al-Kanater Research Station at ElQalyubia Governorate, during the two consecutive years of 2016/2017 and 2017/2018 to investigate the effect of potassium silicate foliar application on growth, productivity and some postharvest treatments on storability of garlic ((Allium sativum L.)" clone sids 40".

In the field experiment, the treatments comprised of control(water spray),foliar application of potassium silicate at 4000,6000 and 8000ppm and plants were sprayed at 30,60 and 90 days after planting.

In the storage experiment, cured bulbs were stored at room temperature conditions and subjected to sixteen postharvest treatments included the previous four treatments (the three potassium silicate levels and control). In addition, three spraying treatments of sodium silicate at $6000 \mathrm{ppm}$, chitosan at $200 \mathrm{ppm}$ and calcium chloride at 3000 ppm both separately and their combinations with potassium silicate (three treatments in field) were done.

The results revealed that, the highest plant length, number of leaves, fresh, dry weightlplant, neck diameter, bulb diameter and chlorophyll content of garlic were achieved from foliar application of potassium silicate at the 4000ppm after 120 days from planting compared to the control. Foliar spray of potassium silicate at 4000 ppm recorded the highest total yield and bulb quality such as bulb diameter, bulb weight/plant, number of cloves, cloves weight, total soluble solids and dry matter of bulbs. Leaf $\mathrm{K}$ percentage significantly increased by spraying of potassium silicate at 6000ppm.Further, all potassium silicate treatments recorded higher silicon percentage over the control.
\end{abstract}

Postharvest results showed that weight loss and shrinking percentages of the bulbs after 7 months of the storage were the least with the foliar application of potassium silicate at $8000 \mathrm{ppm}$ plus chitosan at 200ppm in storage followed by chitosan individually, potassium silicate at 8000 ppm and potassium silicate at $6000 \mathrm{ppm}$ combined with calcium chloride as a postharvest treatment. However, the highest total soluble solids after 7 months of the storage was obtained from foliar spraying of potassium silicate at 4000 ppm combined with either sodium silicate or chitosan. Also, bulbs treated with foliar application of potassium silicate at 6000 or 8000 ppm combined with chitosan at 200 ppm, had the highest values of dry matter after 7 months from storage.

In general, foliar application of potassium silicate at $4000 p p m$ was the superior treatment for enhancing plant growth, yield and quality. Also, foliar application of potassium silicate at $8000 \mathrm{ppm}$ and sprayed with chitosan at $200 \mathrm{ppm}$ was the most effective for garlic storability seven months at the room temperature conditions.

Key words: Garlic, Potassium silicate, Growth, Yield, Chitosan, calcium chloride and storability

\section{INTRODUCTION}

In Egypt, garlic (Allium sativum L.) is consider one of the most important vegetables for both local consumption and exportation. Garlic is a second vital cultivated Allium species after onion worldwide. Garlic is used as a spices, seasonings, condiments, medicinal value. As well as, flavoring for foodstuff involving both green tops and bulbs Dufoo-Hurtado et al 2015). 
Silicon concentration ranges from $1 \%$ to $10 \%$ or higher in plant dry matter (Epstein, 1999). Since plants require silica to resist against biotic and abiotic stress (Ma, 2004), Si has an important potential in the plant growth and development (Datnoff et al., 2001 and Henk 2018).

Potassium application on garlic significantly increased plant growth, yield and its components and concentration of TSS, N, P, K as well as chemical constituents and storability of bulbs (EIMorsy et al 2004). Potassium element is very important in overall metabolism of plant enzymes activity, it was found to serve a vital role in photosynthesis by direct increasing in growth Mansour, (2006). Supplemental dose of potassium as a foliar spray had a significant effect on the onion yield (Ghoname et al 2007).Potassium silicate can improve the physiological response of plant leaves as increased the photosynthetic pigments, compatible solutes, and enzyme activity then improve the ability to resist against white rot disease then increase the yield production of the onion plants (Mamdouh et al 2017).Silicic acid sprays increase growth and yield and decrease biotic and abiotic stress and attributed, these effects to that monosilicic acid is absorbed by the leaf and fulfills a role as a signaling molecule for the activation of growth-promoting and anti-stress hormones (Henk, 2018).

Calcium chloride treatment reduced decay percentage due to the vital roles of calcium in plant tissues, such increase membrane stability, and cell wall strength (Poovaiah et al 1988). As pointed out by Taain (2011) postharvest treatment of jujube fruits with calcium chloride and calcium nitrate decreased the decay of fruits particularly caused by fungi, decreased weight loss. In addition, preharvest applications of $\mathrm{CaCl} 2$ showed improved fruit $\mathrm{Ca}$ concentration, texture, and flavor; and decreased weight loss of papaya (Babak et al 2015). Moreover, $\mathrm{Ca}$ application delays postharvest softening and decreases weight loss tomato fruits (Dhia et al 2017).

Chitosan is a natural antimicrobial biopolymer with a good film forming ability, hence, it is used as an edible coating on whole and fresh cut fruits and vegetables where, Chitosan improves storability of postharvest fruits and vegetables because it forms a semi permeable film that regulates the gas exchange and reduce transpiration and respiration (Shehata et al 2012). Hence weight loss is reduced and fruit ripening is slowed down. This effect has been reported for numerous horticultural commodities such as tomatoes, strawberries (Kittur et al 2001 and Bautista et al 2006) and garlic
(Khreba et al 2014 and El-Sagan and El Dsouky, 2015).

Therefore, this study was carried out to investigate the influence of foliar application of some potassium silicate concentrations on garlic growth .As well as, the effect of spraying chitosan, sodium silicate and calcium chloride on storability improvement.

\section{MATERIALS AND METHODS}

Two field experiments were carried out on garlic (Allium sativum L.) "clone sids 40" during 2016/2017 and 2017\2018 at the experimental farm of Al-Kanater Research Station El-Qalyubia Governorate, Egypt, to investigate the effect of foliar application of potassium silicate levels on growth, yield, its components and storability; as well as the effect of some postharvest treatments on garlic storability, two experiments were conducted:

\section{The first experiment:}

Three concentrations of potassium silicate were foliar sprayed at 4000ppm, 6000ppm ,8000ppm and control (tap water) treatments started after 30, 60 and 90 days from planting. All other agricultural practices were applied according to the recommendation of Hort. Res. Inst., A.R.C. Ministry of Agric. Egypt, under drip irrigation condition. The experimental design was a complete randomized block design with three replicates. Planting dates were at the $4^{\text {th }}$ and $6^{\text {th }}$ of October in the two seasons respectively. Plants were arranged in four row-bed system with $100 \mathrm{~cm}$ width and $30 \mathrm{~cm}$ height. Garlic clove seeds were planted in hills at $10 \mathrm{~cm}$ apart within each row. Planting was done on both sides of each hill and experimental plot area was $20 \mathrm{~m}^{2}$ (four rows with five meters length and $1 \mathrm{~m}$ width).

\section{Data recorded}

\section{Vegetative growth parameters}

After 120 days from planting, ten plants from each experimental plot were randomly selected for measuring the following characters i.e., plant length $(\mathrm{cm})$, number of leaves/plant, fresh and dry weight of plant $(\mathrm{g})$, neck diameter $(\mathrm{cm})$, bulb diameter(cm), and Leaf total chlorophyll readings (SPAD) were measured on attached leaves using a porta- 

growth, Productivity and storability of garlic

ble chlorophyll meter (SPAD-502, Konica Minolta Sensing, Inc., Japan).

\section{Yield and its quality}

At harvest time in $20^{\text {th }}$ May and after curing for 7 days, yield per plot was calculated and yield per fed./ton was estimated according to the yield $\backslash$ plot. Ten bulbs were taken randomly from each experimental plot to measure the bulb quality of the following characters i.e., bulb fresh weight $(\mathrm{g})$, bulb diameter $(\mathrm{cm})$, number and weight of cloves /bulb and bulb ratio were measured.

\section{Chemical composition}

Dry matter (\%)

It was calculated twice, after curing bulbs and after seven months of storage.

\section{Mineral contents}

Silicon and potassium were determined in the digested dry matter of leaves as follows: -Silicon percentage was determined with an inductively coupled plasma (ICP) spectrometer according to Stefansson and Grioud (2007). Potassium percentage was determined by using Flame photometer according to Brown and Lilliland (1946).

\section{Total soluble solid content (TSS)}

Total soluble solid of cloves were taken twice, after curing bulb and after seven months of storage, using a JK-SR-113ATC digital Refractometer (Shanghi Co. Ld., China).

\section{The second experiment}

Included 16 storage treatments to investigate the effect of them on storability of bulbs as follows :

\section{1- Four treatments from field experiment}

Control (tab water), Potassium silicate at three concentrations (4000, 6000 and 8000 ppm).

\section{2-Three postharvest treatments:-}

Sodium silicate at $6000 \mathrm{ppm}$, chitosan at 200 ppm, Calcium chloride at 3000 ppm.

\section{3- Nine treatments combinations}

The previous postharvest treatments were combined with Potassium silicate levels chosen from field treatments at 4000,6000 and 8000ppm.

$1 \mathrm{Kg}$ of uniform bulbs was sprayed after curing by the three postharvest treatments and placed in nets, then distributed in a complete randomized design. Three replicates were prepared for each treatment. All treatments were stored at room temperature at $24 \mathrm{C} \pm 5^{\circ} \mathrm{C}$ with common storage conditions with aeration conditions and stored for seven months at Al-Kanater Horticulture Research Station. The experimental design was a complete randomized design with three replicates in the storage conditions.

\section{Data recorded}

Data were recorded, during the storage period, from seventh and ninth of May until ${ }^{\text {st }}$ and $5^{\text {th }}$ of Decembers in the two growing seasons respectively as follows:-

\section{1- Weight loss}

It was calculated monthly according to the following formula: Weight loss (\%) = initial weight weight of bulbs for sampling dates $\times 100 \backslash$ initial weight of bulb.

\section{2-Shrinking \%}

The percentage of shrinking cloves was calculated monthly according to the following formula: shrinking cloves $(\%)=$ Number of Shrinked cloves /Total number of cloves $\times 100$.

\section{3-Total weight loss percentage}

It was taken after seven months of storage.

\section{Statistical analysis}

Analysis of data was done by IBM computer and means were compared using Duncan's multiple range tested as described according to Snedecor and Cochran (1982).

\section{RESULTS AND DISCUSSION}

\section{1- Field experiment}

\section{Vegetative growth}

Results in Table (1) indicate that the highest plant length was produced from foliar spray with potassium silicate at 6000 or $8000 \mathrm{ppm}$ followed by $4000 \mathrm{ppm}$ in the first season. Moreover, all the concentrations of potassium silicate showed the taller plant length compared with untreated plants in the second season. Also, potassium silicate at $4000 \mathrm{ppm}$ recorded the highest number of leaves 
/plant in the two growing seasons. In this connection, spraying tomato transplants by silicic acid were taller than control (Olle and Schnug, 2016).Also, foliar application of potassium silicate enhanced plant growth as reported by (Diwate, 2018) on sweet orange.

Data in Table (1) indicate that the highest fresh weight per plant was achieved from 4000ppm followed by $8000 \mathrm{ppm}$ in the two tested seasons. Also, the highest dry weight percentage per plant was recorded from the application of potassium silicate at 4000ppm compared with the untreated plants in the two growing seasons. While, in the first season there were no significant differences among the three potassium concentrations. This result was agree with findings of Ali (2017) who found that the foliar spraying with salicylic acid on garlic plants increased plant growth traits, i.e., plant height, both fresh and dry weight/plant.

Table 1. Effect of foliar spray with potassium silicate concentrations on vegetative growth characters of garlic plants at 120 days from planting during 2016/ 2017 and 2017/2018 seasons.

\begin{tabular}{|c|c|c|c|c|c|c|}
\hline Treatments & $\begin{array}{l}\text { Plant length } \\
\text { (cm) }\end{array}$ & $\begin{array}{l}\text { No. leaves } \\
\text { /plant }\end{array}$ & $\begin{array}{c}\text { fresh } \\
\text { weight/ } \\
\text { plant } \\
\text { (g) }\end{array}$ & $\begin{array}{c}\text { dry weight/ } \\
\text { plant } \\
(\%)\end{array}$ & $\begin{array}{l}\text { Neck di- } \\
\text { ameter } \\
\text { (cm) }\end{array}$ & $\begin{array}{c}\text { Bulb diame- } \\
\text { ter } \\
(\mathrm{cm})\end{array}$ \\
\hline \multicolumn{7}{|c|}{$2016 / 2017$} \\
\hline control & $72.40 \mathrm{c}$ & $7.14 \mathrm{c}$ & $76.06 \mathrm{c}$ & $28.48 \mathrm{~b}$ & $1.01 \mathrm{c}$ & $2.06 \mathrm{c}$ \\
\hline potassium silicate4000ppm & $78.71 \mathrm{~b}$ & $9.85 \mathrm{a}$ & $100.76 a$ & $37.20 \mathrm{a}$ & $1.53 \mathrm{a}$ & $3.03 \mathrm{a}$ \\
\hline potassium silicate6000ppm & $81.28 \mathrm{a}$ & $8.56 \mathrm{ab}$ & $84.72 \mathrm{bc}$ & 35.72 a & $1.48 \mathrm{ab}$ & $2.56 \mathrm{~b}$ \\
\hline potassium silicate8000ppm & $81.91 \mathrm{a}$ & $9.06 \mathrm{ab}$ & $89.00 \mathrm{~b}$ & $36.39 \mathrm{a}$ & $1.28 \mathrm{~b}$ & $2.10 \mathrm{c}$ \\
\hline \multicolumn{7}{|c|}{$2017 / 2018$} \\
\hline control & $68.36 \mathrm{~b}$ & $8.61 \mathrm{c}$ & $75.67 b$ & $30.01 \mathrm{c}$ & $1.13 b$ & $2.16 \mathrm{c}$ \\
\hline potassium silicate4000ppm & $80.97 \mathrm{a}$ & $10.20 \mathrm{a}$ & $115.50 \mathrm{a}$ & $40.82 a$ & $1.58 \mathrm{a}$ & $3.05 \mathrm{a}$ \\
\hline potassium silicate6000ppm & $82.65 \mathrm{a}$ & $9.46 \mathrm{~b}$ & $79.67 \mathrm{~b}$ & $36.34 \mathrm{~b}$ & $1.51 \mathrm{ab}$ & $2.62 \mathrm{~b}$ \\
\hline potassium silicate8000ppm & $82.25 \mathrm{a}$ & $9.22 \mathrm{bc}$ & $89.00 a b$ & $35.67 \mathrm{~b}$ & $1.26 \mathrm{~b}$ & $2.21 \mathrm{c}$ \\
\hline
\end{tabular}

Values within the column followed by the same capital /s do not significantly differ from each other

according to Duncan 's multiple range test at $5 \%$ level.

In respect to the neck diameter, results in Table (1) indicate that the highest neck diameters were obtained from both of the application of potassium silicate at 4000 and $6000 \mathrm{ppm}$ in the two tested seasons. In addition, the largest bulb diameter was obtained with the application of potassium silicate at $4000 \mathrm{ppm}$ during the vegetative growth stage in both seasons. In this connection, foliar potassium on garlic plants increased growth characters (Gmaa, 2016) and (Olle and Schnug, 2016) on tomato. Such results are in agreement with findings of Ali (2017) who showed that the foliar spraying with yeast extract and salicylic acid on garlic increased plant growth traits.

Table (2) clearly show that the highest chlorophyll content was observed from foliar spray with potassium silicate at 4000ppm followed by 6000 and $8000 \mathrm{ppm}$ without significant differences between each of them. While, the lowest content of chlorophyll was recorded by the control plants in the two seasons. Application of potassium silicate have accelerated the synthesis of chlorophyll associated with photosynthesis and accumulated carbohydrates that resulted an increase in the size of bulb as indicated by diameter and average bulb weight, as well as ultimately the overall yield. Similar findings were also noticed by Mansour (2006) and Talware et al (2010) on garlic plants and (Mamdouh et al 2017) on onion.

\section{Yield and its components}

Results in Table (2) show that, the foliar application of potassium silicate at 4000 ppm significantly increased yield of bulbs, followed by the treatment of 8000ppm during the two growing seasons. On the other hand, the lowest value of yield was shown by untreated plants (control) in both tested seasons. Supplemental dose of potassium as foliar spray had a significant effect on the onion yield Ghoname et al (2007) and Diwate (2018) on sweet orange. Potassium silicate can improve the 
physiological response of plant leaves as increased the photosynthetic pigments, compatible solutes, and enzyme activity then increase the yield production of the onion plants (Mamdouh et al 2017).

Furthermore, Table (2) showed that the foliar application of potassium silicate at 4000 ppm produced the highest bulb fresh weight /plant followed by $8000 p p m$.On the contrary, the untreated plants produced the lowest values in both seasons. (Shalaby and El-Ramady, 2014 and Ali, 2017) indicated that foliar application of biostimulants on garlic effectively increased yield and quality. In addition, significant increment in bulb diameter with potassium silicate foliar application and the highest bulb diameter was achieved by using 4000ppm followed by $6000 \mathrm{ppm}$ compared with control. Potassium silicate could be affect the final bulb weight and size which improve the total yield. Silicon sprays significantly improved some growth parameters and ground cover (Janmo hammadi, et al 2016) on safflower crop.

Table 2. Effect of foliar spray with potassium silicate concentrations on total chlorophyll, yield and bulb quality in 2016/2017 and 2017/2018 seasons.

\begin{tabular}{|c|c|c|c|c|c|c|c|}
\hline Treatments & \begin{tabular}{|c|} 
Total Chlo- \\
rophyll \\
(SPAD)
\end{tabular} & $\begin{array}{c}\text { Yield } \\
\text { (ton/fed.) }\end{array}$ & $\begin{array}{c}\text { fresh bulb } \\
\text { weight/ } \\
\text { plant (g) }\end{array}$ & $\begin{array}{c}\text { bulb diameter } \\
(\mathrm{cm})\end{array}$ & $\begin{array}{l}\text { No .of } \\
\text { cloves }\end{array}$ & $\begin{array}{c}\text { Clove } \\
\text { weight } \\
\text { (g) }\end{array}$ & $\begin{array}{l}\text { bulbing } \\
\text { ratio }\end{array}$ \\
\hline \multicolumn{8}{|c|}{$2016 / 2017$} \\
\hline Control & $69.59 \mathrm{c}$ & $5.92 \mathrm{c}$ & $61.38 c$ & $4.17 \mathrm{~d}$ & $23.00 \mathrm{c}$ & $2.35 \mathrm{c}$ & $0.59 \mathrm{~b}$ \\
\hline potassium silicate4000ppm & $83.44 \mathrm{a}$ & $10.38 \mathrm{a}$ & $77.33 a$ & $6.11 \mathrm{a}$ & $26.20 \mathrm{a}$ & $4.08 \mathrm{a}$ & $0.69 a b$ \\
\hline potassium silicate6000ppm & $77.42 \mathrm{~b}$ & $7.88 \mathrm{~b}$ & $69.90 \mathrm{~b}$ & $5.36 \mathrm{~b}$ & $22.93 \mathrm{c}$ & $3.52 \mathrm{ab}$ & $0.68 a b$ \\
\hline potassium silicate $8000 \mathrm{ppm}$ & $78.46 \mathrm{~b}$ & $7.793 \mathrm{~b}$ & $71.40 \mathrm{~b}$ & $4.60 \mathrm{c}$ & $25.00 \mathrm{~b}$ & $3.24 b$ & $0.74 \mathrm{a}$ \\
\hline \multicolumn{8}{|c|}{$2017 / 2018$} \\
\hline Control & $73.59 \mathrm{c}$ & $7.51 \mathrm{~d}$ & $50.5 d$ & $4.56 \mathrm{~d}$ & $23.05 a$ & $1.94 \mathrm{~b}$ & $0.61 \mathrm{c}$ \\
\hline potassium silicate4000ppm & $85.71 \mathrm{a}$ & $12.18 \mathrm{a}$ & $74.1 \mathrm{a}$ & $6.69 \mathrm{a}$ & $22.33 a$ & $3.75 \mathrm{a}$ & $0.75 b$ \\
\hline potassium silicate $6000 \mathrm{ppm}$ & $80.92 b$ & $8.81 \mathrm{c}$ & $56.13 c$ & $5.71 \mathrm{~b}$ & $24.00 \mathrm{a}$ & $3.33 \mathrm{a}$ & $0.62 c$ \\
\hline potassium silicate $8000 \mathrm{ppm}$ & $81.09 \mathrm{~b}$ & $9.89 \mathrm{~b}$ & $68.25 \mathrm{~b}$ & $4.80 \mathrm{c}$ & $22.50 \mathrm{a}$ & $3.08 \mathrm{a}$ & $0.86 \mathrm{a}$ \\
\hline
\end{tabular}

Values within the column followed by the same capital /s do not significantly differ from each other according to Duncan 's multiple range test at $5 \%$ level

Table (2) clearly showed that foliar application with potassium silicate at 4000 ppm gave the highest number of cloves followed by 8000ppm in the first season. However, there were no significant differences between all treatments in the second season. Results are in harmony with Gmaa (2016) who demonstrated that stimulants not significantly affect number of cloves. Also, foliar spray with 4000ppm and $6000 \mathrm{ppm}$ recorded the highest weight of cloves following by $8000 \mathrm{ppm}$ compared to the control which recorded the lowest weight of cloves in the two seasons. In addition, the bulbing ratio was significantly increased by the different treatments compared to the control. Where, the application of potassium silicate at 8000 recorded the highest values of bulb ratio in the two tested seasons. In this connection, foliar application of potassium on garlic plants increased growth characters (Gmaa, 2016) on garlic and (Olle and Schnug, 2016) on tomato. This is in agreement with findings of Ali, (2017) who showed that the foliar spraying with yeast extract and salicylic acid on garlic increased plant growth traits and bulbing ratio.

Data in Table (3) show that the highest potassium leaves concentrations was observed from foliar spraying with potassium silicate at $6000 \mathrm{ppm}$ and there were no significant differences among $4000,8000 p p m$ and control in the two tested seasons. Additionally, the highest values of silicon content of leaves was recorded by spraying 4000ppm and there were no significant differences between 6000 or 8000 ppm compared with control in the first and second seasons. Similar findings were obtained by Praksh et al (2011) they showed that application of silicon increased the shoot silicon concentration of rice and Ali (2017) demonstrated that the interaction between foliar spray with yeast extract and salicylic acid increased $\mathrm{K}$ content in garlic leaves. Moreover, Satisha et al (2017) found that application of Potassium silicate on chili increased nutrient uptake 
In respect to bulb total soluble solids content at harvest, data showed that spraying with potassium silicate at $4000 \mathrm{ppm}$ produced the highest values followed by 8000 ppm in the first season. In addition, the foliar application of potassium silicate at 4000 and 8000 ppm had significant increment of total soluble solids content in the second season.

Table 3. Effect of foliar spray with potassium silicate concentrations on Potassium, silicon, total soluble solids and dry matter contents of garlic in 2016/2017 and 2017/2018 seasons.

\begin{tabular}{|c|c|c|c|c|}
\hline Character & $\begin{array}{c}\text { Potassium\% } \\
\text { of leaves }\end{array}$ & $\begin{array}{l}\text { Silicon\% } \\
\text { of leaves }\end{array}$ & $\begin{array}{c}\text { TSS } \\
\text { Of } \\
\text { bulbs }\end{array}$ & $\begin{array}{c}\text { Dry } \\
\text { matter \% } \\
\text { of bulbs }\end{array}$ \\
\hline \multicolumn{5}{|c|}{$2016 / 2017$} \\
\hline \multirow{4}{*}{$\begin{array}{c}\text { control } \\
\text { Potassium sili- } \\
\text { cate4000ppm } \\
\text { potassium sili- } \\
\text { cate6000ppm } \\
\text { potassium sili- } \\
\text { cate8000ppm }\end{array}$} & $1.22 \mathrm{~b}$ & $1.65 b$ & $37.30 \mathrm{c}$ & $28.16 \mathrm{~d}$ \\
\hline & $1.24 b$ & $3.16 a$ & $40.80 a$ & $35.24 \mathrm{a}$ \\
\hline & $1.56 a$ & $2.49 a b$ & $39.40 \mathrm{~b}$ & $30.50 \mathrm{c}$ \\
\hline & $1.24 b$ & $2.43 a b$ & $40.10 b$ & $33.10 \mathrm{~b}$ \\
\hline \multicolumn{5}{|c|}{$2017 / 2018$} \\
\hline \multirow{4}{*}{$\begin{array}{c}\text { control } \\
\text { potassium sili- } \\
\text { cate4000ppm } \\
\text { potassium sili- } \\
\text { cate6000ppm } \\
\text { potassium sili- } \\
\text { cate8000ppm }\end{array}$} & $1.27 \mathrm{~b}$ & $1.79 b$ & $38.90 \mathrm{c}$ & $40.44 \mathrm{c}$ \\
\hline & $1.39 b$ & $2.98 a$ & $42.10 a$ & $51.95 \mathrm{a}$ \\
\hline & $1.96 a$ & $2.79 a$ & $40.40 b$ & $47.16 b$ \\
\hline & $1.21 \mathrm{~b}$ & $2.98 a$ & 41.00ab & $48.27 \mathrm{~b}$ \\
\hline
\end{tabular}

Values within the column followed by the same capital/s do not significantly differ from each other according to Duncan 's multiple range test at $5 \%$ level

On the other hand, the control recorded the lowest values of total soluble solids content in the two seasons (Table 3). The increment in the percentage of total soluble solids may be due to the reduction of moisture content of bulbs and the lower moisture content of the fruit increases the concentration of the cell juice of the bulbs and thus increases the percentage of soluble solids as mentioned by (Burton 1982). Similarly, potassium silicate at $4000 \mathrm{ppm}$ recorded the highest values of dry matter percentage of bulbs at harvest followed by 6000 or $8000 p p m$. On the contrary, the untreated plants produced the lowest dry matter of bulbs in two tested seasons. These findings are similar with Gmaa (2016) who demonstrated that dry matter of bulb was increased by spraying with potassium oxide on garlic plants.

\section{2- The second experiment (storage experiment)}

\section{Weight loss percentage}

It is clear from data presented in Table (4) that there were significant differences among the different treatments of postharvest in weight loss percentage after two, four and seven months of the storage. The foliar application of potassium silicate at 8000 ppm individually or plus chitosan at 200 ppm and the treatment of chitosan at $200 \mathrm{ppm}$ recorded the lowest weight loss values followed by the foliar application of potassium silicate at 6000 ppm plus calcium chloride at 3000 ppm compared with the other tested treatments.

Presented results are agreement with those obtained by Babak et al (2015) who showed that Preharvest applications of $\mathrm{CaCl}_{2}$ decreased weight loss of papaya.

In this aspect, potassium silicate at $8000 \mathrm{ppm}$ without postharvest treatments had less weight loss percentage (Table 4). These results may be due to the stimulatory effect of silicon on growth parameters, which may be reflected on quality and storability of garlic bulbs during storage. On the other side, the highest weight loss percentage was obtained with control treatment or spraying of potassium silicate 4000 ppm field treatment plus calcium chloride 3000 ppm in both seasons. The effect of spraying chitosan on garlic bulbs storability due to the positive effect of chitosan that extend the storage through the reduction of respiration rate and water loss. Coating fruits with semi permeable film has generally been shown to retard ripening by modifying the endogenous $\mathrm{CO}_{2}, \mathrm{O}_{2}$, and ethylene levels of fruits (EI Ghaouth et al 1991).

Chitosan coating is likely to modify the internal atmosphere without causing anaerobic respiration, since chitosan films are more selectively permeable to $\mathrm{O}_{2}$ than to $\mathrm{CO}_{2}$ Shehata et al (2012). These results may be due to the stimulatory effect of silicon on growth parameters, which may be reflected on quality and storability of garlic bulbs during storage. Chitosan is a natural biopolymer with a good film forming ability, hence, it is used as an edible coating on vegetables and fruits (Khreba et al 2014 and El-Sagan and El Dsouky, 2015). Ca application as postharvest treatment decrease weight loss of tomato fruits (Dhia et al 2017). 

growth, Productivity and storability of garlic

Table 4. Effect of foliar spray of potassium silicate levels and postharvest treatments on weight loss \% after two, four and seven months of the storage periods during 2016/2017 and 2017/2018 seasons.

\begin{tabular}{|c|c|c|c|c|c|c|}
\hline \multirow{3}{*}{ Treatments } & \multicolumn{6}{|c|}{ weight loss $\%$} \\
\hline & \multicolumn{2}{|c|}{ After 2 month } & \multicolumn{2}{|c|}{ After 4 month } & \multicolumn{2}{|c|}{ After 7 month } \\
\hline & Season1 & Season2 & Season1 & Season2 & Season1 & Season2 \\
\hline Control & $21.63 \mathrm{a}$ & $21.81 \mathrm{ab}$ & $25.80 \mathrm{a}$ & $28.16 \mathrm{ab}$ & $33.47 \mathrm{abc}$ & $29.48 \mathrm{abcd}$ \\
\hline Potassium silicate 4000ppm & $13.56 \mathrm{bcd}$ & $19.63 \mathrm{abc}$ & 16.60 bcdefg & $23.71 \mathrm{bcd}$ & $35.12 a b$ & $34.82 \mathrm{ab}$ \\
\hline Potassium silicate 6000ppm & 11.00 def & 14.05 ef & 18.78 bcde & 17.62 efg & 31.41 bcde & $25.97 \mathrm{de}$ \\
\hline Potassium silicate $8000 \mathrm{ppm}$ & $8.50 \mathrm{fg}$ & $11.02 \mathrm{fg}$ & 18.58 bcdef & $15.60 \mathrm{fg}$ & $26.08 \mathrm{f}$ & $23.47 \mathrm{de}$ \\
\hline Sodium silicate $6000 \mathrm{ppm}$ & 10.30 defg & 16.40 cde & 15.37 defg & $22.37 \mathrm{cde}$ & $33.50 a b c$ & 26.83 bcde \\
\hline Chitosan 200ppm & 9.80 efg & 13.37 ef & $14.30 \mathrm{fg}$ & $20.91 \mathrm{de}$ & 27.99 def & 26.10 cde \\
\hline calcium chloride $3000 \mathrm{ppm}$ & 12.23 cde & 14.49 def & 17.35 bcdef & 21.57 cde & 27.21 ef & $25.37 \mathrm{de}$ \\
\hline $\begin{array}{l}\text { Potassium silicate } 4000 \mathrm{ppm}+ \\
\text { Sodium silicate } 6 \mathrm{~cm} / \mathrm{L}\end{array}$ & $15.03 \mathrm{bc}$ & $22.79 a b$ & $20.77 \mathrm{~b}$ & $26.38 \mathrm{abc}$ & 31.12 bcde & $34.13 a b c$ \\
\hline $\begin{array}{l}\text { Potassium silicate } 4000 \mathrm{ppm}+ \\
\text { Chitosan200ppm }\end{array}$ & 13.02 cde & 19.27 bc & $17.25 \mathrm{bcdef}$ & 22.05 cde & 29.63cdef & $35.53 \mathrm{a}$ \\
\hline $\begin{array}{l}\text { Potassium silicate } 4000 \mathrm{ppm}+ \\
\text { calcium chloride } 3000 \mathrm{ppm}\end{array}$ & $16.87 \mathrm{~b}$ & $23.20 \mathrm{a}$ & $19.45 \mathrm{bcd}$ & 29.27 a & $35.51 \mathrm{ab}$ & $37.23 \mathrm{a}$ \\
\hline $\begin{array}{l}\text { Potassium silicate } 6000 \mathrm{ppm}+ \\
\text { Sodium silicate } 6 \mathrm{~cm} / \mathrm{L}\end{array}$ & $13.73 \mathrm{bcd}$ & $16.30 \mathrm{cde}$ & 18.10bcdef & $22.52 \mathrm{cde}$ & $35.59 a b$ & 26.30 cde \\
\hline $\begin{array}{l}\text { Potassium silicate 6000ppm + } \\
\text { Chitosan200ppm }\end{array}$ & 11.70 cdef & 14.69 def & 16.20 cdefg & 20.30 def & $36.22 \mathrm{a}$ & $30.20 \mathrm{abcd}$ \\
\hline $\begin{array}{l}\text { Potassium silicate } 6000 \mathrm{ppm}+ \\
\text { calcium chloride } 3000 \mathrm{ppm}\end{array}$ & 11.00 def & 13.27 ef & 16.90bcdefg & $18.39 \mathrm{efg}$ & 29.60 cdef & $24.93 \mathrm{de}$ \\
\hline $\begin{array}{l}\text { Potassium silicate } 8000 p p m+ \\
\text { Sodium silicate } 6 \mathrm{~cm} / \mathrm{L}\end{array}$ & 10.60 defg & $16.08 \mathrm{cde}$ & 14.47 efg & 20.20 def & $32.41 \mathrm{bcde}$ & 26.47 cde \\
\hline $\begin{array}{l}\text { Potassium silicate 8000ppm + } \\
\text { Chitosan200ppm }\end{array}$ & $7.53 \mathrm{~g}$ & $9.36 \mathrm{~g}$ & $12.57 \mathrm{~g}$ & $14.82 \mathrm{~g}$ & 27.59 ef & $18.83 \mathrm{e}$ \\
\hline $\begin{array}{l}\text { Potassium silicate } 8000 \mathrm{ppm}+ \\
\text { calcium chloride } 3000 \mathrm{ppm}\end{array}$ & $14.83 \mathrm{bc}$ & $17.97 \mathrm{bc}$ & $19.93 \mathrm{bc}$ & $21.50 \mathrm{cde}$ & 28.59 def & 26.77 bcde \\
\hline
\end{tabular}

Values within the column followed by the same capital /s do not significantly differ from each other according to Duncan 's multiple range test at $5 \%$ level.

\section{Shrinking percentage}

Results in Table (5) showed that the lowest value of shrinking percentage was recorded for foliar application with potassium silicate at 8000 ppm plus chitosan at $200 \mathrm{ppm}$ as a postharvest treatment without significant difference with coating chitosan at $200 \mathrm{ppm}$ followed by those sprayed with potassium silicate at $6000 \mathrm{ppm}$ in the field and treated with calcium chloride at $3000 \mathrm{ppm}$. On the other hand, the highest values were recorded for control and spraying of potassium silicate at 4000 ppm plus calcium chloride at $3000 \mathrm{ppm}$ in the two seasons. In this connection, calcium treatment may be improved storability of postharvest vegetables, hence, calcium involved in plant cell wall integrity and has been reported in its role in improving storage life of several fruits and increased fruit firmness (Ghani et al 2010). Also, chitosan improves storability of postharvest fruits and vegetables because it forms a semi permeable film that regulates the gas exchange and reduce transpiration and respiration (Shehata et al 2012). 
Table 5. Effect of foliar spray of potassium silicate levels and postharvest treatments on shrinking, total weight loss, total soluble solids and dry matter Percentages after seven months of the storage during 2016/2017 and 2017/2018 seasons.

\begin{tabular}{|c|c|c|c|c|c|c|c|c|}
\hline \multirow{2}{*}{$\begin{array}{l}\text { Character } \\
\text { Treatments }\end{array}$} & \multicolumn{2}{|c|}{ Shrinking \% } & \multicolumn{2}{|c|}{ Total weight loss $\%$} & \multicolumn{2}{|c|}{ TSS \% } & \multicolumn{2}{|c|}{ Dry matter \% } \\
\hline & Season1 & Season2 & Season1 & Season2 & Season1 & Season2 & Season1 & Season2 \\
\hline Control & $33.58 \mathrm{ab}$ & $45.15 \mathrm{a}$ & $46.07 \mathrm{ab}$ & $49.53 \mathrm{a}$ & $38.67 a b$ & $39.67 \mathrm{~cd}$ & $38.73 \mathrm{~h}$ & $40.00 \mathrm{~g}$ \\
\hline $\begin{array}{l}\text { Potassium silicate } \\
\text { 4000ppm } \\
\text { Potassium silicate } 6\end{array}$ & $30.31 \mathrm{bcd}$ & 30.98 efg & $47.87 \mathrm{a}$ & $48.53 \mathrm{ab}$ & $38.00 \mathrm{abc}$ & 38.33 de & $40.36 \mathrm{fgh}$ & $44.67 \mathrm{de}$ \\
\hline $\begin{array}{l}\text { 000ppm } \\
\text { Potassium silicate }\end{array}$ & $29.21 \mathrm{bcd}$ & $39.58 \mathrm{bc}$ & $41.80 \mathrm{abcd}$ & 30.90def & $34.33 \mathrm{gh}$ & 37.87 ef & 43.06def & $45.00 \mathrm{~d}$ \\
\hline 8000ppm & 27.32 def & $33.93 \mathrm{de}$ & $45.00 \mathrm{abc}$ & 30.37def & 36.37cdef & 37.60 ef & $48.67 \mathrm{bc}$ & $51.00 \mathrm{~b}$ \\
\hline Sodium silicate $6000 \mathrm{ppm}$ & 26.28defg & $28.91 \mathrm{fgh}$ & 39.00 bcde & $44.23 a b c$ & 36.27 def & $39.00 \mathrm{cde}$ & $40.37 f g h$ & $42.33 \mathrm{f}$ \\
\hline Chitosan 200ppm & $21.79 \mathrm{gh}$ & $25.16 \mathrm{hi}$ & 37.13 cde & 31.10def & 36.00 efg & $36.67 \mathrm{fg}$ & 43.87de & $51.00 \mathrm{~b}$ \\
\hline $\begin{array}{l}\text { calcium chloride } \\
3000 \text { ppm } \\
\text { Potassium silicate } \\
\text { 4000ppm + Sodium sili- }\end{array}$ & $32.11 \mathrm{bc}$ & 33.54 def & 39.43abcde & $39.40 \mathrm{bcd}$ & 37.79abcd & $39.67 \mathrm{~cd}$ & $39.50 \mathrm{gh}$ & 43.00 ef \\
\hline $\begin{array}{l}\text { cate } 6 \mathrm{~cm} / \mathrm{L} \\
\text { Potassium silicate } \\
4000 \mathrm{ppm}+\end{array}$ & $27.63 \mathrm{cdef}$ & 33.54 def & $44.57 \mathrm{abc}$ & $36.37 \mathrm{cde}$ & $39.00 \mathrm{a}$ & $41.20 \mathrm{ab}$ & $48.69 \mathrm{bc}$ & $45.67 d$ \\
\hline $\begin{array}{l}\text { Chitosan200ppm } \\
\text { Potassium sili- } \\
\text { cate4000ppm + calcium }\end{array}$ & $22.26 \mathrm{gh}$ & $36.23 \mathrm{~cd}$ & 38.00 bcde & $49.40 \mathrm{a}$ & $39.10 \mathrm{a}$ & $41.67 \mathrm{a}$ & $45.72 \mathrm{~cd}$ & $48.00 \mathrm{c}$ \\
\hline $\begin{array}{l}\text { chloride 3000ppm } \\
\text { Potassium silicate } \\
6000 \text { ppm + }\end{array}$ & $38.00 \mathrm{a}$ & $41.39 \mathrm{ab}$ & $41.00 \mathrm{abcd}$ & $42.93 a b c$ & $38.00 \mathrm{abc}$ & $40.17 \mathrm{bc}$ & 42.00efg & 43.00ef \\
\hline $\begin{array}{l}\text { Sodium silicate } 6 \mathrm{~cm} / \mathrm{L} \\
\text { Potassium silicate } \\
6000 \mathrm{ppm}+\end{array}$ & 28.08 cde & 32.61 def & $43.77 a b c$ & $45.97 a b c$ & 37.17bcde & $38.53 \mathrm{de}$ & 43.06def & $45.00 \mathrm{~d}$ \\
\hline $\begin{array}{l}\text { Chitosan200ppm } \\
\text { Potassium silicate } \\
\text { 6000ppm + calcium chlo- }\end{array}$ & $28.46 \mathrm{cde}$ & 33.41 def & $41.28 \mathrm{abcd}$ & $49.40 \mathrm{ab}$ & 36.13 def & 38.00 ef & $54.26 \mathrm{a}$ & $56.33 a$ \\
\hline $\begin{array}{l}\text { ride 3000ppm } \\
\text { Potassium silicate } \\
8000 \text { ppm + }\end{array}$ & $24.41 \mathrm{efg}$ & 29.48efgh & $31.17 \mathrm{de}$ & 28.10 ef & 37.17bcde & 39.00 cde & 40.33fgh & 43.00ef \\
\hline $\begin{array}{l}\text { Sodium silicate } 6 \mathrm{~cm} / \mathrm{L} \\
\text { Potassium silicate } \\
8000 \mathrm{ppm}+\end{array}$ & 28.74 cde & $42.12 a b$ & $41.10 \mathrm{abcd}$ & 29.07 ef & $34.67 \mathrm{fgh}$ & $36.00 \mathrm{gh}$ & $48.96 b$ & $51.83 b$ \\
\hline Chitosan200ppm & $19.36 h$ & $20.67 i$ & $34.37 \mathrm{de}$ & $24.83 \mathrm{f}$ & $34.00 \mathrm{~h}$ & $35.00 \mathrm{~h}$ & $56.17 a$ & $55.33 a$ \\
\hline ride 3000 ppm & $23.25 \mathrm{fgh}$ & $26.19 \mathrm{gh}$ & $45.67 \mathrm{abc}$ & $36.20 \mathrm{cde}$ & 37.83abcd & $38.57 \mathrm{de}$ & 42.16efg & 44.00def \\
\hline
\end{tabular}

Values within the column followed by the same capital /s do not significantly differ from each

other according to Duncan 's multiple range test at $5 \%$ level

Furthermore, results are harmony with those reported by Shalaby and El-Ramady (2014) on garlic; they noticed that plants sprayed with some biostimulants had better storability of bulbs than the control.

\section{Total weight loss}

Data in Table (5) show that bulbs received foliar application of potassium silicate at $8000 \mathrm{ppm}$ plus chitosan at $200 \mathrm{ppm}$ after 7 months in storage resulted in the lowest values of total weight loss percentages and without significant difference with the treatment sprayed with potassium silicate at $6000 \mathrm{ppm}$ in the field combined with calcium chloride at $3000 \mathrm{ppm}$ and the treatment of chitosan at $200 \mathrm{ppm}$ compared with the other treatments. It is noted that the fruits soaked with calcium chloride solution decreased the percentage of loss in weight because of calcium increases cell wall strength and reduces the decomposition of pectin and wax layer surrounding the fruit epidermis, which leads to reduce the evaporation of water content of fruits Taain (2011) on jujube fruits

\section{Total soluble solids content}

It is obvious from results in Table (5) that the highest total soluble solids after 7 months of storage were obtained from foliar spraying of potassium silicate at $4000 \mathrm{ppm}$ combined with sodium silicate at $6000 \mathrm{ppm}$ or with chitosan at $200 \mathrm{ppm}$ in both seasons. While, the lowest total soluble solids resulted from spraying of potassium silicate at 

growth, Productivity and storability of garlic

8000 ppm combined with chitosan at 200 ppm or sodium silicate at $6000 \mathrm{ppm}$ in the two tested seasons. Increasing in TSS during storage may result from an increase in concentration of organic solutes as a consequence of water loss. Smith et al (1979) reported that increased in TSS may occur due to numerous anabolic and catabolic processes taking place in apple, preparing it for senescence. The metabolic process related to the advance of ripening, probably due to disassociation of some molecules and structural enzymes in soluble compounds directly influence the levels of total soluble solids, where fruits in advanced stage of ripening present the highest levels of soluble solids (Lyon et al 1992) on persimmons. These results agree with those of Gmaa (2016) on garlic who mentioned the total soluble solids of cloves increased as prolonged storage period owing to the greater degradation or biosynthesis of the polysaccharides and accumulation of sugars

\section{Dry matter}

Data listed in Table (5) show that significant differences were found among the different treatments on dry matter after seven months from storage, the highest values were obtained from foliar application of potassium silicate at $6000 \mathrm{ppm}$ plus chitosan at 200 ppm and foliar application of potassium silicate at $8000 \mathrm{ppm}$ plus chitosan 200. On the other hand, untreated bulbs and calcium chloride at $3000 \mathrm{ppm}$ produced the lowest values of dry matter. These results are in agreement with those of Nurzynsk and Wierdak(1998) they found that dry matter content has increased as the storage duration increased of peeled garlic. The increase in dry matter content during storage months could be due to moisture losses from the outer skin over the storage period. This result is supported by work Henriksen and Hansen (2001) they showed slight increase in dry matter and accounted it to loss of moisture from the bulbs as well as to hydrolysis of fructans upon termination of the dormancy where the bulbs began to sprout. Similar results were also observed by Currah and Rabinowitch (2002) on onion and by Sebsebe et al (2010) on shallot.

\section{Conclusion}

The study recommends applying potassium silicate at $4000 \mathrm{ppm}$ to increase growth, yield and quality of garlic bulbs. In addition, foliar application of potassium silicate at $8000 \mathrm{ppm}$ in field and treated bulbs with chitosan at 200 ppm enhanced storability of garlic followed by foliar application of po- tassium silicate at 6000ppm and treated with calcium chloride at $3000 \mathrm{ppm}$ or treated with chitosan at $200 \mathrm{ppm}$.

\section{REFERENCES}

Ali, M.A.M. 2017 Effect of some Bio-stimulants on Growth, Yield and Bulb Quality of Garlic J. Plant Production, Mansoura Univ., 12, 12851294.

Babak, M., Wall M., Mirshekari A., Bah A. and Mahmud T.M.M. 2015. Influence of Calcium Foliar Fertilization on Plant Growth, Nutrient Concentrations, and Fruit Quality of Papaya Hort., Technology. 25(4), 496- 504.

Bautista-Banos, S., A.N. Hernández-Lauzardo and M.G. Velázquez-del Valle. 2006. Chitosan as a potential natural compound to control pre and postharvest diseases of horticultural commodities. Crop Protection, 25, 108-118.

Brown, J.D. and Lilliland O. 1946. Rapid determination of potassium and sodium in plant material and soil extracts by flame photometry. Proc. Amer. Soc. Horticulture. Sci., 48, 341346.

Burton W.G. 1982. Postharvest Physiology of Food Crops. Lougman, New York, USA, 310 p.

Currah, L. and Rabinowitch H.D. 2002. Allium Crop Science: Recent Advances, CABI publishing, Israel, pp. 329-515.

Datnoff, L.E., Synder G.H. and Korndorfer G.H., 2001. Silicon in Agriculture. Elsevier Science, New York, USA, pp. 171-179.

Dhia A.T., Abdul K.M.A. and Jaber N.A.Z. 2017. Effect of pre and post-harvest treatment with plant extracts and calcium chloride on storage ability of tomato Lycopersicon esculentum Mill. fruits grown in plastic greenhouse AAB Bioflux, 9(3), 161-172.

Diwate, D.D. 2018. Response of soil and foliar application of silicon on growth, yield and quality parameters of sweet orange (citrus sinensisl. osbeck) cv. Nucellar M.Sc. Thesis, Horticulture Dep. College of Agriculture, Badnapur Vasantrao Naik Marathwadakrishi Vidyapeeth, Parbhani, India, 109p.

Dufoo-Hurtado, M.D., Huerta-Ocampo J.A., Barrera-Pacheco A., Barba de la Rosa A.P. and Mercado-Silva E.M. 2015. Low temperature conditioning of garlic (Allium sativum L.) "seed" cloves induces alterations in sprouts proteome. Frontiers in Plant Science, 6 (332), 1- 15. 
El Ghaouth, A., Arul J., Ponnampalam R. and Boulet M. 1991.Chitosan coating effect on storability and quality of fresh strawberries. J. Food Sci., 56, 1618-1620.

El-Morsy, A.H.A., El-Shal Z.S. and Sarg M.H. 2004. Effect of potassium application methods and some micronutrients on growth, yield and storability of garlic. J. Agric. Sci. Mansoura Univ., 29 (4), 2013.2023.

EI Sagan, M.A.M. and EI Dsouky G.A. 2015. Effect of irrigation systems and chitosan on productivity of garlic under Siwa conditions. Zagazig J. Agric. Res, 42 (6), 427- 439.

Epstein, E. 1999. Silicon Annu. Rev. Plant Physiol. PI. Mol. Biol., 50, 641-644.

Ghani, M.A.A., Awang Y. and Sijam K. 2010. Disease occurrence and fruit quality of preharvest calcium treated red flesh dragon fruit (Hylocereus polyrhizus). African Journal of Biotechnology 10(9), 1550-1558.

Ghoname A., Fawzy Z.F., El-Bassiony A.M., Riadand G.S. and Abd El-Baky M.M.H. 2007. Reducing Onion Bulbs Flaking and Increasing Bulb Yield and Quality by Potassium and Calcium Application. Australian Journal of Basic and Applied Sciences, 1(4), 610-618.

Gmaa, S.S. 2016. Improving yield, quality and storage ability of garlic (Allium sativum I.) by pre-harvest foliar application J. Plant Production, Mansoura Univ., 7(1), 7- 12.

Henk, M.L. 2018. The Effects of Foliar Sprays with Different Silicon Compounds. Plants, 7(45), 122.

Henriksen, K. and Hansen S.L. 2001. Increasing the dry matter production in bulb onions (Allium cepaL.). Acta Horticulturae. 555, 147-152.

Janmo Hammadi, M., Amanzadeh T., Sabaghnia N. and Ion V. 2016. Effect of nano-silicon foliar application on safflower growth under organic and inorganic fertilizer regimes. Bot. Lith. 22, 53-64.

Khreba, A.H., Hassan A.H., Emam M.S. and S.A. 2014. Effect of some pre and postharvest treatments on quality and storability of strawberry fruits. Journal of American Science, 10(11), 239-248.

Kittur, F.S., Kumar K.R. and Tharanathan R.N. 2001. Functional packaging properties of chitosan films. Z. Lebensm Unters Sorsh A., 206, 44-47.

Lyon, B.G., Senter S.D. and Payne J.A. 1992. Quality characteristics of oriental persimmons (Diospyrus kaki, L.) cv.Fuyu grows in the southeastern United States. J. Food Sci., 57, 693-695.

Ma, J.F. 2004. 'Role of silicon in enhancing the resistance of plants to biotic and abiotic stresses', Soil Sci. Plant Nutr., 50, 11-18.

Mamdouh M.A.Kh., Fetian N.A.H, Medhat S., Abdel Magid S. and El-Sheery N.I. 2017. Effectiveness of Potassium Silicate in Suppression White Rot Disease and Enhancement Physiological Resistance of Onion Plants, and its Role on the Soil. Middle East Journal of Agriculture Research, 6(2), 1-19.

Mansour, F.Y.O. 2006. Physiological studies on garlic (Allium sativum L.). M.Sc. Thesis, Fac. Agric., Minufiya Univ., Egypt, 159p.

Nurzynsk, A. and Wierdak R. 1998. Changes in chemical composition during garlic storage under different conditions. Annales Universitati Smariae Curie Skodowska Section EEE Horticultura., 6, 9-16.

Olle, M. and Schnug E. 2016. The effect of foliar applied silicic acid on growth and chemical composition of tomato transplants. J. Kulturpflanzen, 68, 241-243.

Poovaiah B.W., Glenn G.M. and Reddy A.S.N. 1988. Calcium and fruit softening: physiology and biochemistry. In: Horticultural Reviews. 10, 107-152.

Praksh B., Chandrashekhar N., Mahendra C., Patil S.U., Thippeshappa G.N. and Laane H.M. 2011. Effect of foliar spray of soluble silicic acid on growth and yield parameters of wet land rice in hilly and coastal zone soils of Karnataka, South India, J. Plant Nutr., 34 (12), 1883-1893.

Satisha, G.C., Saxena A.K. and Ganesshamurthy A.N. 2017. Effect of silicon and macronutrients on plant growth, yield and disease incidence in chilli (Capsicum annuum L). In Proceedings of the $7^{\text {th }}$ International Conference on Silicon in Agriculture, Bengaluru, India, 24-28 October, $144 \mathrm{p}$.

Sebsebe, Z., Woldetsadik K. and Workneh T. 2010. Effects of nitrogen levels, harvesting time and curing on quality of shallot bulb. African Journal of Agricultural Research, 5(24), 3342-3353.

Shalaby, T.A. and El-Ramady H. 2014. Effect of foliar application of bio-stimulants on growth, yield, components, and storability of garlic (Allium sativum L.). Australian Journal Crop Science, 8 (2), 271-275.

Shehata, S.A., Fawzy Z.F. and El-Ramady H.R 2012. Response of cucumber plants to foliar 

growth, Productivity and storability of garlic

application of chitosan and yeast under greenhouse. Australian J. Basic Appl. Sci., 6 (4), 63-71.

Smith, R.B., Lougheed E.C., E.W. Franklin and McMillan I. 1979. The starch iodine test for determining stage of maturation in apples. Canadian J. Plant Sci., 59, 725-735.

Snedecor, G.W. and Cochran W.G. 1982. Statistical Methods. $2^{\text {nd }}$ Printing, lowa State Univ., Press, Ames, USA, 507p.

Stefansson, A.I. and Giroud N. 2007. New method for the direct determination of dissolved in organic and total carbon in natural waters by regent-free ion chromatography and inductively coupled plasma atomic emission spectrometry. Anal. Chim. Acta, 582 (1), 69-74.

Taain D. A., 2011. Effect of storage temperatures and postharvest calcium salts treatments on storability of Jujube fruits (ZizphusmauritianaLam. CV. Tufahi). Annals of Agricultural Science, Mosahtohor 49(4), 447-453.

Talware P., Dubay S., Gupta N.K. and Jain P.K. 2010. Effect of organic, inorganic and biofertilizers on the growth and productivity of garlic (Allium sativum L.) CV. G-223. National Symposium on Alliums. Current Scenario and Emerging Trends. 18 p. 


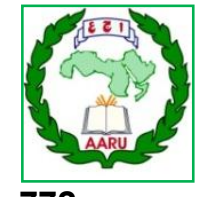

المؤتمر الرابع عشر لبحوث التنمية الزراعية،

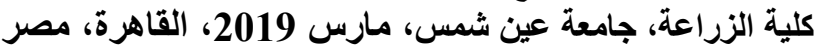

مجلد(27)، عدد (1)، عداء خاص مارس، .........

تأثير الرش بسيليكات البوتاسيوم ويعض معاملات ما بعد الحصاد علي النمو والإنتاجية والقررة التخزينية في الثوم

[70]

\author{
أماني عطية عبد اللطيف- نادية محمد ابراهيم - شادية عبد التلاه إسماعيل \\ قسم البطاطس والخضر خضرية التكاثر - معهد بحوث البساتين ـالجيزة- مصر
}

*Corresponding author: nadia_mohamed33@yahoo.com

Received 20 February, 2019, Accepted 26 May, 2019

أوضحت نتائج التجربة الحقلية أن صفات كل من

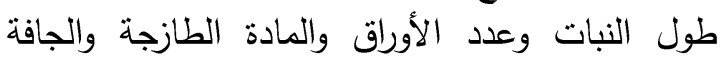
للنبات وقطر كلا من العنق والبصلة و ونسبة الكلوروفيل

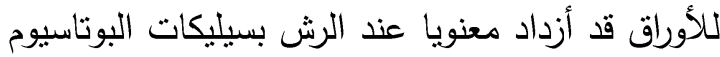

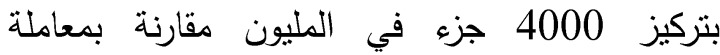

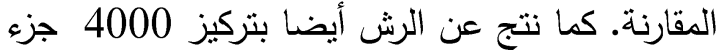

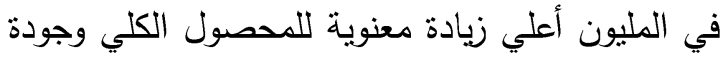
الأبصال (قطر ووزن البصلة وعدد ووزن الفصاد الفصوص

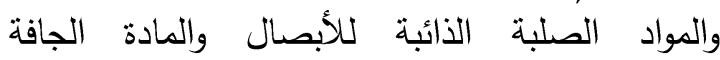

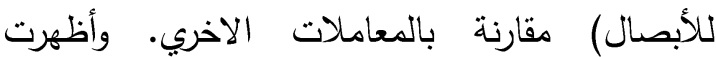
المعاملة بسيليكات البوتاسيوم بتركيز

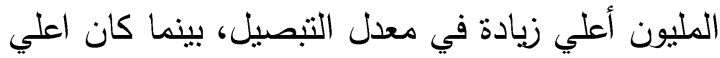

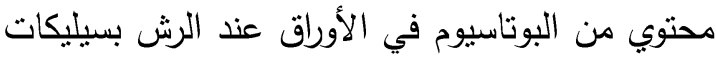

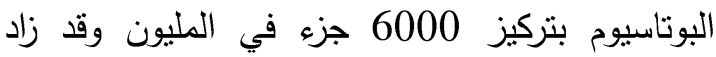
محتوي الأوراق من السيليكون معنويا بكل التركيزات مقارنة بمعاملة المقارنة. أظهرت نتائج تجربة التخزين أن معاملة الأبصال

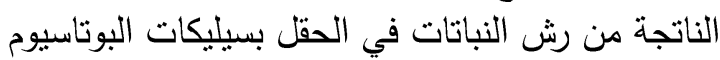
بتركيز 8000 جزء في المليون ثم معاملتها بالثيتوسان 200 جزء في المليون في المخزن كانت أفضل النتائج

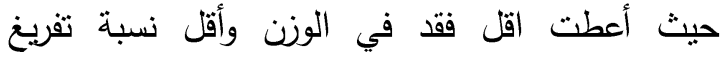
للأبصال ويليها كلا من المعاملة بالثيتيتوسان بتركيز

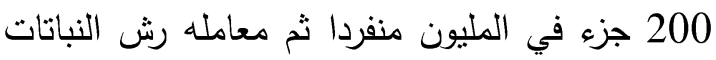
بسيليكات البوتاسيوم بتركيز 6000 جزي في المليون يليها معامله الرش بكلوريد الكالسيوم بتركيز 3000

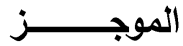

اجريت هذه التجربة في محطة بحوث البساتين

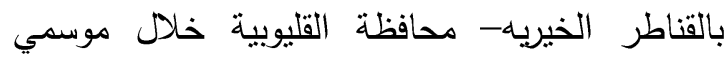
2017/2016 و2017/ 2018 لدراسة تاثير الرش فئل بسيليكات البوتاسيوم وبعض معاملات ما بعد الحصاد

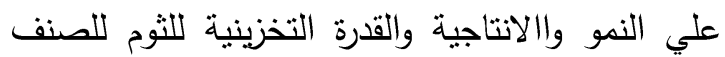
سدس 40 في تجربتين علي النحو التالي: 1-تجربة حقلية: الرش بسيليكات البوتاسيوم بثلاث تركيزات وهي 4000 - 6000 - 8000 جزء في المليون وميزات ومعاملة المقارنة (الرش بالماء). وتم إجراء الرش بعد 30 و 60 و و90 يوم من الزراعة وكان تصميم التجربة في في في قطاعات كاملة العشوائية بثلاث مكررات

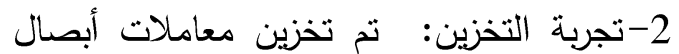

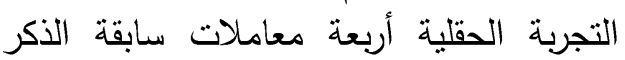
بالإضافة إلي ثلاث معاملات ما بعد الحصاد

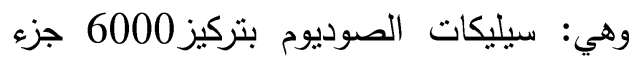
في المليون والثيتوسان 200 جزء في المليون

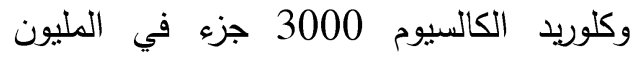
وكذاللك التوافقات التسعة بين معاملات الحقل

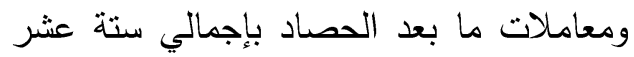

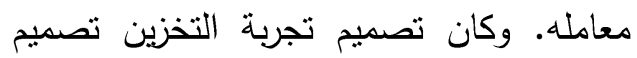
تام العشوائية بثلاث مكررات.

تحكيم: ا.د محمد إمام رجب

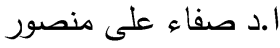


بالثيتوسان بتركيز 200 جزء في المليون أعلي القيم

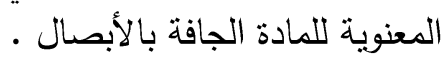

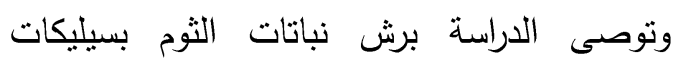

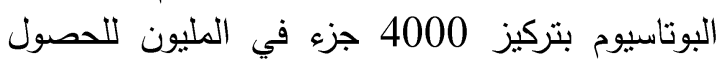

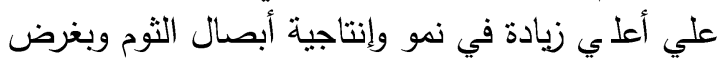

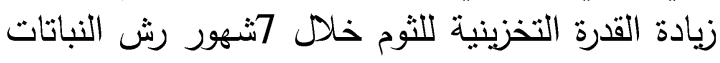

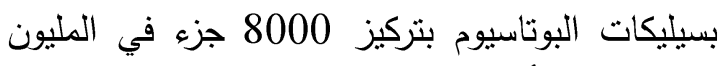
مع معامله الأبصال الناتجة بالثيتوسان بتركيز جزء في المليون تحت ظروف الابصال الغرفة العادية العان.
جزء في المليون علي التوالي لفترة 7 شهور من التخزين في درجة حرارة الغرفة. كما أدي شي النباتات بسيليكات البوتاسيوم 4000

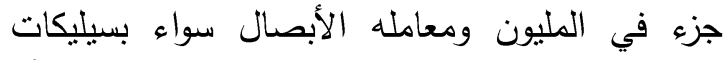

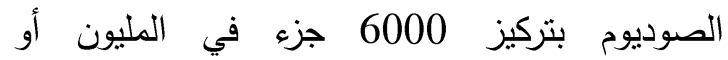
بالثيتوسان بتركيز 200 جزء في المليون عند التخزين فئي

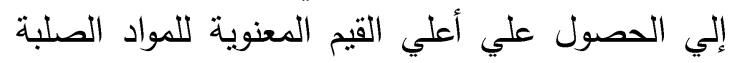

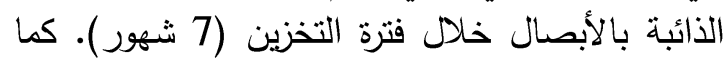
أظهرت معامله الرش بكل من سيليكات البوت فئناسيوم 6000 أو 8000 جزء في المليون مع معامله الأبصال 